\title{
Evaluation of mental health and anxiety level among hepatitis $C$ patients during COVID-19 pandemic in Pakistan
}

\author{
Sadia Rafique ${ }^{1}$, Muhammad Saleem Khan ${ }^{1 *}$ D, Rabia Unar ${ }^{2}$, Muhammad Wajid $^{1}$, Ahmad Waheed ${ }^{1}$ and Ali Umar ${ }^{1}$
}

\begin{abstract}
Background: This study was conducted to check anxiety level and mental stress in the 200 confirmed hepatitis C patients during the COVID-19 pandemic. The Chinese version of the Beck Anxiety Inventory (BAI) score index was used to measure the anxiety level of HCV-positive patients. BAI score index of different demographic factors such as gender, age, occupation, and education of all the sampled population was calculated.

Results: The highest BAI score was recorded in people in the age group of 25-45 years (54.5\%). Respondents from public sector employees, own businesses, and postgraduates were highly anxious. A significant difference in BAl score was also recorded between male and female respondents as $33.77 \%$ of females were at a severe level of anxiety compared to $17.07 \%$ of males. Furthermore, quarantined hepatitis $C$ patients had a significantly higher BAI score (39.5) as compared to non-quarantined patients (27.12), and respondents with HCV infection also had a high BAI score of 37.25 compared to healthy individuals (4.1). Most of the respondents were willing to adopt protective measures against COVID-19.
\end{abstract}

Conclusion: This study concluded that people with infectious diseases like hepatitis $C$ had high anxiety levels and mental stress in the COVID-19 pandemic and needed psychological aids for better mental health to handle pandemic conditions.

Keywords: Hepatitis C, COVID-19, Anxiety, Mental health, Pakistan

\section{Background}

Hepatitis is a serious health concern around the globe and especially in developing countries in Asia [1]. Hepatitis $\mathrm{C}$ virus (HCV) is the causative agent of hepatitis $\mathrm{C}$ and $3 \%$ of the world's population is infected by this virus. Chronic hepatitis $C$ damages hepatic tissues and, in some cases, also develops hepatic carcinoma and hepatic cirrhosis [2].

When a person is infected by $\mathrm{HCV}$, the virus influences the immune system and destroys the recognition and defense system of the host body. Acute or mild infections have less impact on immunology, but if left

\footnotetext{
* Correspondence: SamiiKhan@uo.edu.pk

${ }^{1}$ Department of Zoology, Faculty of Life Sciences, University of Okara, Okara 56130, Pakistan

Full list of author information is available at the end of the article
}

untreated for a long period of time, the infection can progress to a chronic condition that reduces patients' immunity. These immunosuppressed patients have more chances of developing severe complications in other diseases like COVID-19 than healthier persons [3].

COVID-19 is a pandemic viral infection, caused by a coronavirus (SARS-CoV-2). The outbreak began in Wuhan (China) and spread throughout the world [4]. To date, 151,916,040 people have been infected and 3,190, 948 deaths have been reported globally due to the COVID-19 pandemic [5]. This pandemic also increases anxiety, depression, and restlessness in immunesuppressed individuals such as HCV-infected people.

Psychological problems are often observed in patients suffering from chronic $\mathrm{HCV}$ or undergoing $\mathrm{HCV}$ treatment such as riboflavin and PegIFNa (pegylated 
interferon-alpha). The most frequent and serious side effect of antiviral therapy is depression and poor mental health [6]. Several other factors, such as thinking of being affected by a deadly disease, the negative social impact, and higher complications, are responsible for psychological problems [7]. People are affected very badly in respect of mental health due to the COVID-19 pandemic [8], and this also increases anxiety and stress in HCV patients as recorded in this study. The lockdown situation further increases problems for chronic patients like $\mathrm{HCV}$ in terms of availability of medicine and fear of being infected with COVID-19 infection, and this was proved in previous studies by Guerriero et al. [9] that lockdown increases the functional neurological symptoms of mental health disorder by 3.4-fold. Furthermore, similar stressful conditions and anxiety were recorded in individuals that were in direct contact with Ebolainfected individuals (2018) in the Democratic Republic of the Congo and Sierra Leone [10]. Seeing the current situations, this study was designed to find out the anxiety level in $\mathrm{HCV}$-infected individuals.

\section{Methods}

\section{Sample population}

A cross-sectional study was conducted in different hospitals in Punjab, Pakistan, on a random basis for 4 months. The sample size consisted of $200 \mathrm{HCV}$ infected patients, who were approached and interviewed in hospitals. Verbal consent was obtained from all individual participants before the interview and the consent was approved by the Ethical Committee, University of Okara (reference number: UO/DOZ/2020/ misc.). It was made sure that the ethical standards involving human participants were followed by all means according to the ethical standards of the Ethical Committee, University of Okara, as well as the 1964 Helsinki Declaration and its later amendments or comparable ethical standards.

\section{Assessment of anxiety level}

To evaluate the anxiety level, the Chinese version of the Beck Anxiety Inventory (BAI)-based questionnaire was used. This version was used successfully to evaluate the anxiety levels in Chinese populations [11, 12]. The BAI consisted of different questions that describe symptoms of anxiety. Respondents were asked to rate their anxiety level with symptoms on a 4-point Likert type $(0-3)$. The total score ranged between 0 and 63 was used to rate each individual on the anxiety scale [13]. BAI scores were categorized into 4 levels. Normal respondents had scores ranging from 0 to 9 , mild or moderate 10-18, moderate to severe 19-29, and severe 30-63 [14].

\section{Statistical analysis}

The demographic profile of the sample and BAI scores were characterized by descriptive statistics. Minitab V.17 was used as a statistical tool to analyze the data.

\section{Results}

The study population consisted of 200 confirmed HCVinfected patients that regularly visited the hospitals. Out of total respondents, $61.5 \%(\mathrm{n}=123)$ were male and $38.5 \%(\mathrm{n}=77)$ were female. Most of the respondents $(\mathrm{n}$ $=109,54.5 \%$ ) were between the ages of 25 and 45 . Respondents were of different professions, like labor (maximum, 20.5\%) and students (7.5\% being minimum). The educational levels of respondents were different from undergraduate (49\%), graduate (36.5\%), and postgraduate $(14.5 \%)$ as represented in Table 1.

It was widely assumed that COVID-19 outbreaks cause anxiety and mental stress in the general population. We investigated whether this outbreak also affects patients with compromised immunity, i.e., HCV-infected patients. For this purpose, we recorded the BAI score in $\mathrm{HCV}$ patients. There was a significant difference in BAI scores between males and females. A high BAI score was recorded in the age group of 25-45 years, which showed severe anxiety levels in this age group in $\mathrm{HCV}$-infected patients. Furthermore, we also checked whether the demographic characters influence the BAI score or not.

Table 1 Demographic characteristics of HCV-positive participants

\begin{tabular}{lll}
\hline $\begin{array}{l}\text { Participant } \\
\text { characteristics }\end{array}$ & Respondents \\
\cline { 2 - 3 } Gender & 123 & $\%$ \\
Male & 77 & 61.5 \\
Female & & 38.5 \\
Age & 11 & \\
$\leq 25$ years & 109 & 5.5 \\
25-45 years & 80 & 54.5 \\
$>45$ years & & 40 \\
Occupation & 15 & \\
Student & 36 & 7.5 \\
Teachers & 15 & 18 \\
Unemployed & 40 & 7.5 \\
Agriculture & 20 & 20 \\
Own business & 41 & 10 \\
Labor workers & 33 & 20.5 \\
Public sector employee & & 16.5 \\
Education & 98 & 49.5 \\
Undergraduate & 73 & \\
Graduate & 29 & \\
Postgraduate & & \\
\hline
\end{tabular}



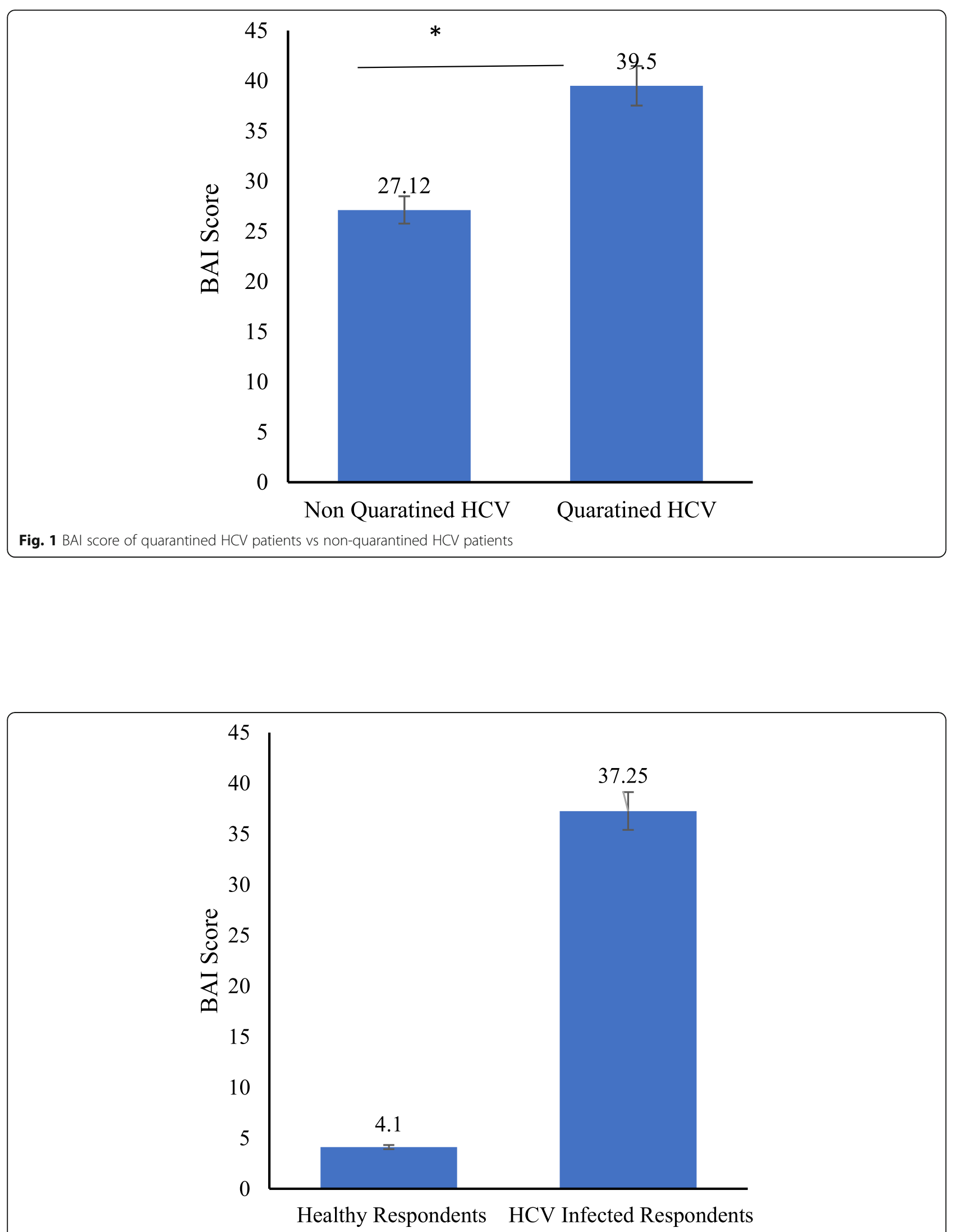

Fig. 2 BAl score of healthy vs HCV-positive patients 
Unlike others, a very low level of anxiety was recorded among HCV-infected students as most $(80 \%)$ of students have BAI level 1.

The quarantined $\mathrm{HCV}$ patients had a significantly higher BAI score as compared to non-quarantined $\mathrm{HCV}$ patients (Fig. 1), while HCV-positive patients had a highly significant BAI score as compared to healthy individuals (Fig. 2).

Among the professions, the highest percentage of respondents with their business $(50 \%)$ were at a severe anxiety level $(30-63 \%)$. The same was in the case of postgraduate patients (Table 2).

The comparison of BAI scores of HCV-positive quarantined and $\mathrm{HCV}$-positive non-quarantined patients showed that quarantined respondents had a significantly higher BAI score compared to non-quarantined patients (Fig. 3).

Table 3 shows that most of the respondents were very conscious of adopting protective measures against being infected by COVID-19. For example, $82.5 \%$ of respondents were in the habit of using masks when they went outside their homes. The respondents were using hand sanitizers (47\%), and soap (53\%) for washing their hands.
$82.5 \%$ of respondents were frequently washing their hands. $67 \%$ of people agreed to quarantine if symptoms of COVID-19 were experienced (Fig. 4).

\section{Discussion}

This study aimed to record the anxiety level in HCVpositive respondents in response to the COVID-19 outbreak in the Pakistani population. It was hypothesized that the average BAI score will be higher in HCV patients compared to normal individuals. Our hypothesis was supported by the investigation of $[11,12]$ as their BAI score of the general population of China in an epidemic-free environment was significantly lower than the sampled population in the present study. Moreover, it was found that hepatitis $C$ patients that were quarantined $(\mathrm{n}=32)$ at the time of sampling had a higher BAI score as compared to patients that were not quarantined. These results support the view that human mental health is significantly affected by communicable diseases [15]. In fact, during the West African Ebola virus disease (EVD) outbreak, healthcare workers confirmed that, in addition to deaths and sadness, mental health services were disrupted due to the intense emotional stress faced

Table 2 BAl score of the HCV-infected respondents classified in various subsamples

\begin{tabular}{|c|c|c|c|c|c|c|}
\hline \multirow[t]{2}{*}{ Subsamples } & \multicolumn{5}{|l|}{ BAI score } & \multirow[b]{2}{*}{$\mathbf{P}$} \\
\hline & $0-9$ n (\%) & $10-18(\%)$ & $19-29(\%)$ & $30-63(\%)$ & $x^{2}$ & \\
\hline \multicolumn{7}{|l|}{ Gender } \\
\hline Male $(n=123)$ & $45(36.59 \%)$ & $30(24.39 \%)$ & $27(21.95 \%)$ & $21(17.07 \%)$ & \multirow[t]{2}{*}{13.070} & \multirow[t]{2}{*}{0.004} \\
\hline Female $(n=77)$ & $13(16.88 \%)$ & $16(20.78 \%)$ & $22(28.57 \%)$ & $26(33.77 \%)$ & & \\
\hline \multicolumn{7}{|l|}{ Age } \\
\hline$\leq 25$ years $(n=11)$ & $8(72.73 \%)$ & $2(18.18 \%)$ & 1 (9.09\%) & 0 & \multirow[t]{3}{*}{13.041} & \multirow[t]{3}{*}{0.042} \\
\hline $25-45$ years $(n=109)$ & $29(26.61 \%)$ & $31(28.44 \%)$ & $18(16.51 \%)$ & $31(28.44 \%)$ & & \\
\hline$>45$ years $(n=80)$ & $31(38.75 \%)$ & $21(26.25 \%)$ & $14(17.5 \%)$ & $14(17.5 \%)$ & & \\
\hline \multicolumn{7}{|l|}{ Occupation } \\
\hline Students $(n=15)$ & $12(80 \%)$ & $3(20 \%)$ & 0 & 0 & \multirow[t]{7}{*}{94.589} & \multirow[t]{7}{*}{0.001} \\
\hline Teachers $(n=36)$ & $4(11.11 \%)$ & $12(33.33 \%)$ & $10(27.78 \%)$ & $10(27.78 \%)$ & & \\
\hline Unemployed ( $\mathrm{n}=15)$ & $2(13.33 \%)$ & $3(20.00 \%)$ & $8(53.33 \%)$ & $2(13.33 \%)$ & & \\
\hline Agriculture $(n=40)$ & $26(65 \%)$ & $11(27.50 \%)$ & 0 & $3(7.50 \%)$ & & \\
\hline Own business $(n=20)$ & $2(10 \%)$ & 0 & $8(40 \%)$ & $10(50 \%)$ & & \\
\hline Labor workers $(n=41)$ & $12(29.27 \%)$ & $12(29.27 \%)$ & $14(34.15 \%)$ & $3(7.32 \%)$ & & \\
\hline Public sector employee $(n=33)$ & $3(9.09 \%)$ & $8(24.24 \%)$ & $10(30.30 \%)$ & $12(36.36 \%)$ & & \\
\hline \multicolumn{7}{|l|}{ Education } \\
\hline Undergraduate $(\mathrm{n}=98)$ & $63(64.29 \%)$ & $24(24.49 \%)$ & $6(6.12 \%)$ & $5(5.10 \%)$ & \multirow[t]{3}{*}{55.165} & \multirow[t]{3}{*}{0.002} \\
\hline Graduate $(n=73)$ & $34(46.58 \%)$ & $3(4.11 \%)$ & $24(32.88 \%)$ & $12(16.44 \%)$ & & \\
\hline Postgraduate $(n=29)$ & $5(17.24 \%)$ & $9(31.03 \%)$ & $5(17.24 \%)$ & $10(34.48 \%)$ & & \\
\hline \multicolumn{7}{|l|}{ Quarantined } \\
\hline Yes $(n=32)$ & 0 & 0 & $11(33.37 \%)$ & $21(66.63 \%)$ & \multirow[t]{2}{*}{45.183} & \multirow[t]{2}{*}{0.004} \\
\hline No $(n=168)$ & $67(39.88 \%)$ & $32(19.04 \%)$ & $40(23.81 \%)$ & $29(17.26 \%)$ & & \\
\hline
\end{tabular}




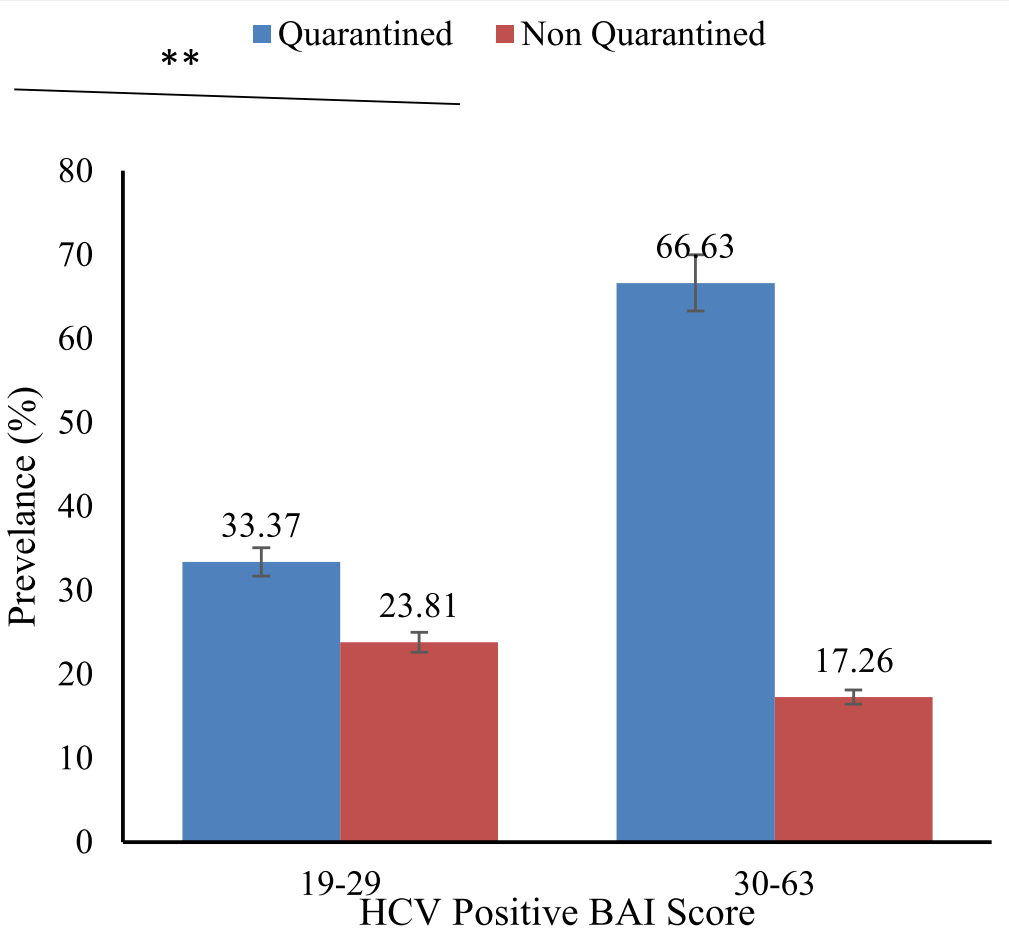

Fig. 3 Prevalence in HCV-positive quarantined vs HCV-positive non-quarantined patients

by patients and their family members, as well as by medical professionals [16].

Out of $200 \mathrm{HCV}$-positive patients, quarantined $(\mathrm{n}=$ 32) patients showed a higher BAI score compared to non-quarantined most probably due to COVID-19 symptoms like sneezing, coughing, difficulty in breathing, malaise, or fever, in the quarantine period, as higher scores of depression subscale as well as Depression, Anxiety and Stress Scale (DASS) were seen in people feeling cold, sore throat, nausea, shortness of breath, and coryza in other studies [17]. Furthermore, the highest BAI score in quarantined patients could be due to viral infection, as found in previous studies, such as the association of neuropsychiatric disease with Borna virus [15], the anxiety experienced by SARS patients [18], and psychological issues such as frustration, depression, fear, anxiety, and suicidal ideation in SARS patients as well [14].

We found a significant difference in the anxiety of females and males, with more anxiety levels in females compared to males. China, Turkey, Italy, and Spain, all have reported similar results [17, 19-21]. A study by Rehman et al. [22] also recorded no significant difference in the anxiety of both sexes in the COVID-19 pandemic. The respondents in the age group of 25-45 years showed higher anxiety levels as compared to the youngsters ( $\leq$ 25 years) and older people ( $>45$ years), and this might be due to 25-45-year-old participants are the backbone of

Table 3 Prevalence of anxiety-related symptoms in HCV-infected respondents regarding COVID-19

\begin{tabular}{lllllll}
\hline Sr \# & Parameters & $\begin{array}{l}\text { Yes } \\
\mathbf{n}(\%)\end{array}$ & $\begin{array}{l}\text { No } \\
\mathbf{n}(\%)\end{array}$ & $\begin{array}{l}\text { Not sure } \\
\mathbf{n}(\%)\end{array}$ & $\mathbf{X}^{\mathbf{2}}$ & $\mathbf{P}$ \\
\hline 1 & Restless due to social distancing? & $109(54.5 \%)$ & $69(34.5 \%)$ & $22(11 \%)$ & 56.89 & 0.05 \\
2 & Significant weight loss or gain & $69(34.5 \%)$ & $117(58.5 \%)$ & $14(7 \%)$ & 79.69 & 0.003 \\
3 & Insomnia or excessive sleep & $69(34.5 \%)$ & $124(62 \%)$ & $7(3.50 \%)$ & 102.79 & 0.004 \\
4 & Repeated thoughts of death? & $84(42 \%)$ & $105(52.5 \%)$ & $11(5.5 \%)$ & 73.03 & 0.013 \\
5 & Lacking interest in daily life? & $123(61.5 \%)$ & $48(24 \%)$ & $29(14.5 \%)$ & 74.11 & 0.012 \\
6 & Fear leaving house & $83(41.5 \%)$ & $107(53.5 \%)$ & $10(5 \%)$ & 76.57 & 0.001 \\
7 & Avoided avail healthcare facilities & $116(58 \%)$ & $63(31.5 \%)$ & $21(10.5 \%)$ & 67.99 & 0.011 \\
8 & Limited physical contact & $164(82 \%)$ & $26(13 \%)$ & $10(5 \%)$ & 215.08 & 0.004 \\
9 & Avoid watching the news & $116(58 \%)$ & $74(37 \%)$ & $10(5 \%)$ & 85.48 & 0.002 \\
\hline
\end{tabular}



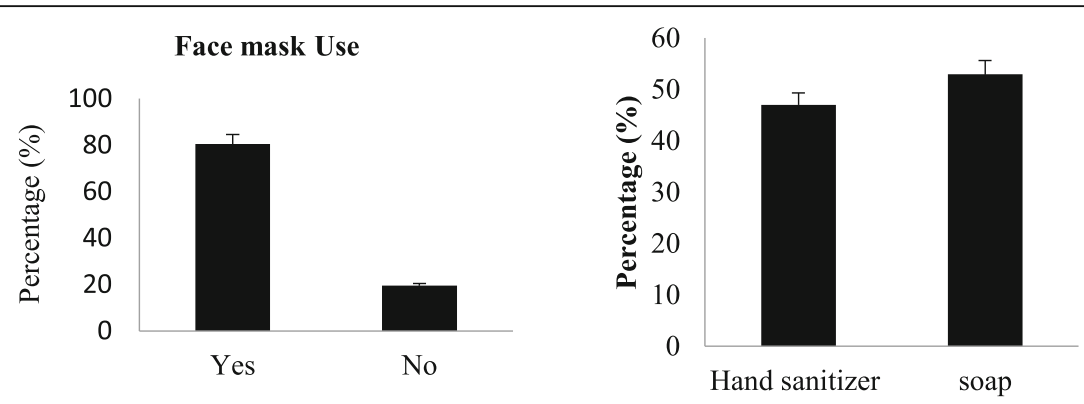

\section{Frequent Hands wash}
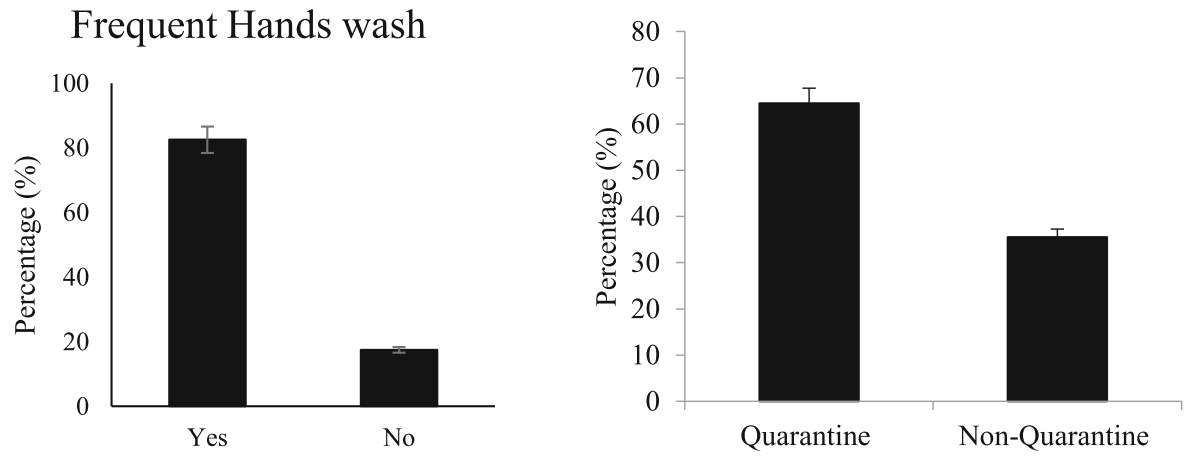

Fig. 4 Percentage proactive measures taken by HCV-infected respondents against COVID-19 infection

their family and they have more burdens of life as well as responsibilities compared to other age groups. Moreover, older people have had more severe anxiety (17.5\%) as compared to younger ones. This could be due to a fear of death and dying as a result of an unknown disease. Our study differed in this aspect from Shah et al. [23] and Ozamiz-Etxebarria et al. [24] who found elevated levels of anxiety in age groups 18-24 and 18-26 respectively.

In a comparison based on occupation, those who had owned a business were more anxious (50\%) than all other categories, followed by those who worked in the public sector (36.36\%). Students found normal (80\%) than teachers $(11.11 \%)$. These outcomes were also opposed to the study of Shah et al. [23] and Cao et al. [25] who found higher levels of anxiety in students, while Rehman et al. [22] found a moderate level of anxiety in students, researchers, and health professionals in India. Furthermore, postgraduates also had anxiety levels (34.48\%) followed by graduates $(16.44 \%)$ and undergraduates $(5.10 \%)$. This finding contradicted the findings of Zhao et al. [26] who discovered that people in high school or below experienced severe anxiety in China due to COVID-19.

\section{Conclusion}

This study concluded that people with infectious diseases such as hepatitis $C$ have higher anxiety levels during COVID-19 pandemic conditions and require adequate psychological aids for better mental health.

\section{Abbreviations}

BAl: Beck Anxiety Inventory; SARS-CoV-2: Severe acute respiratory syndrome coronavirus 2; DASS: Depression, Anxiety and Stress Scale; EVD: Ebola virus disease; HCV: Hepatitis C virus; MERS: Middle East respiratory syndrome; SARS: Severe acute respiratory disease

\section{Acknowledgements}

The authors are thankful to the Faculty of Zoology and Vice-chancellor, University of Okara, for providing support to complete this research.

\section{Authors' contributions}

$\mathrm{SR}, \mathrm{RU}$, and MW collected the data. MSK, AW, and AU organized the data, performed the statistical analysis, and prepared the manuscript. All authors read and approved the final manuscript.

\section{Funding}

This study is a product of the authors' efforts and did not receive any funding from any source.

\section{Availability of data and materials Not applicable.}

\section{Declarations}

Ethics approval and consent to participate

All procedures performed in studies involving human participants were in accordance with the ethical standards of the Ethical Committee, University of Okara (reference number: UO/DOZ/2020/misc.), and with the 1964 Helsinki declaration and its later amendments or comparable ethical standards. Verbal consent was obtained from all individual participants included in the study and the consent was approved by the Ethical Committee, University of Okara (reference number: UO/DOZ/2020/misc.).

Consent for publication

Not applicable.

\section{Competing interests}

The authors declare that they have no competing interests. 


\section{Author details}

'Department of Zoology, Faculty of Life Sciences, University of Okara, Okara 56130, Pakistan. ${ }^{2}$ Jinnah Post Graduate Medical Center Hospital, Karachi, Pakistan.

Received: 16 February 2021 Accepted: 2 June 2021

Published online: 12 June 2021

\section{References}

1. Lu SN, Chen TM, Lee CM, Wang JH, Tung HD, Wu JC (2003) Molecular epidemiological and clinical aspects of hepatitis $D$ virus in a unique triple hepatitis viruses (B, C, D) endemic community in Taiwan. J Med Virol 70(1): 74-80. https://doi.org/10.1002/jmv.10361

2. Mehmood S, Raza H, Abid F, Saeed N, Rehan HM, Javed S, Khan MS (2019) National prevalence rate of hepatitis $B$ and $C$ in Pakistan and its risk factors. J Public Health 28(6):1-14. https://doi.org/10.1007/s10389-019-01081-5

3. Netski DM, Mosbruger T, Depla E, Maertens G, Ray SC, Hamilton RG, Roundtree S, Thomas DL, McKeating J, Cox A (2005) Humoral immune response in acute hepatitis C virus infection. Clin Infect Dis 41(5):667-675. https://doi.org/10.1086/432478

4. Ebrahim SH, Ahmed QA, Gozzer E, Schlagenhauf P, Memish ZA (2020) Covid-19 and community mitigation strategies in a pandemic. British Medical Journal Publishing Group. https://doi.org/10.1136/bmj.m1066

5. Worldometers (2021) COVID-19 coronavirus pandemic. https://www. worldometers.info/coronavirus/.

6. Schaefer M, Capuron L, Friebe A, Diez-Quevedo C, Robaeys G, Neri S, Foster GR, Kautz A, Forton D, Pariante CM (2012) Hepatitis C infection, antiviral treatment and mental health: a European expert consensus statement. J Hepatol 57(6):1379-1390. https://doi.org/10.1016/j.jhep.2012.07.037

7. Fontana RJ, Hussain KB, Schwartz SM, Moyer CA, Su GL, Lok AS (2002) Emotional distress in chronic hepatitis C patients not receiving antiviral therapy. J Hepatol 36(3): 401-407. https:/doi.org/10.1016/s0168-8278(01)00280-x

8. Ma K, Zhang Y, Hou T, Wu M, Cai W, Wen T (2020) Investigation of physical and mental health in isolated people during the outbreak of novel coronavirus pneumonia. Chin J Clin Med 27(01):36-40

9. Guerriero RM, Pier DB, De Gusmão CM, Bernson-Leung ME, Maski KP, Urion DK, Waugh JL (2014) Increased pediatric functional neurological symptom disorders after the Boston Marathon bombings: a case series. Pediatr Neurol 51(5):619-623. https://doi.org/10.1016/j.pediatrneurol.2014.07.011

10. Park J-S, Lee E-H, Park N-R, Choi YH (2018) Mental health of nurses working at a government-designated hospital during a MERS-CoV outbreak: a crosssectional study. Arch Psychiatr Nurs 32(1):2-6. https://doi.org/10.1016/j.a pnu.2017.09.006

11. Huang W-L, Chen T-T, Chen I-M, Chang L-R, Lin Y-H, Liao S-C, Gau SS-F (2016) Harm avoidance and persistence are associated with somatoform disorder psychopathology: a study in Taiwan. J Affect Disord 196:83-86. https://doi.org/10.1016/j.jad.2016.02.009

12. Huang W-L, Chen T-T, Chen I-M, Ma H-M, Lee M-T, Liao S-C, Gau S-F (2016) Depression and anxiety among patients with somatoform disorders, panic disorder, and other depressive/anxiety disorders in Taiwan. Psychiatry Res 241:165-171. https://doi.org/10.1016/j.psychres.2016.05.008

13. Beck AT, Epstein N, Brown G, Steer RA (1988) An inventory for measuring clinical anxiety: psychometric properties. J Consult Clin Psychol 56(6):893897. https://doi.org/10.1037/0022-006x.56.6.893

14. Cheng SK-W, Tsang JS-K, Ku K-H, Wong C-W, Ng Y-K (2004) Psychiatric complications in patients with severe acute respiratory syndrome (SARS) during the acute treatment phase: a series of 10 cases. Br J Psychiatry 184(4):359-360. https://doi.org/10.1192/bjp.184.4.359

15. Tucci V, Moukaddam N, Meadows J, Shah S, Galwankar SC, Kapur GB (2017) The forgotten plague: psychiatric manifestations of Ebola, Zika, and emerging infectious diseases. J Glob Infect Dis 9(4):151-156. https://doi. org/10.4103/jgid.jgid_66_17

16. Reardon S (2015) Ebola's mental-health wounds linger in Africa: health-care workers struggle to help people who have been traumatized by the epidemic. Nature 519(7541):13-15. https://doi.org/10.1038/519013a

17. Wang C, Pan R, Wan X, Tan Y, Xu L, Ho CS, Ho RC (2020) Immediate psychological responses and associated factors during the initial stage of the 2019 coronavirus disease (COVID-19) epidemic among the general population in China. Int J Environ Res Public Health 17(5):1729. https://doi. org/10.3390/ijerph17051729
18. Maunder R, Hunter J, Vincent L, Bennett J, Peladeau N, Leszcz M, Sadavoy J, Verhaeghe LM, Steinberg R, Mazzulli T (2003) The immediate psychological and occupational impact of the 2003 SARS outbreak in a teaching hospital. CMAJ 168(10):1245-1251

19. Özdin S, Bayrak Özdin Ş (2020) Levels and predictors of anxiety, depression and health anxiety during COVID-19 pandemic in Turkish society: the importance of gender. Int J Soc Psychiatry 66(5):504-511. https://doi.org/1 $0.1177 / 0020764020927051$

20. Wang C, Horby PW, Hayden FG, Gao GF (2020) A novel coronavirus outbreak of global health concern. Lancet 395(10223):470-473. https://doi. org/10.1016/S0140-6736(20)30185-9

21. Ozamiz-Etxebarria N, Dosil-Santamaria M, Picaza-Gorrochategui M, IdoiagaMondragon N (2020) Niveles de estrés, ansiedad y depresión en la primera fase del brote del COVID-19 en una muestra recogida en el norte de España. Cad Saúde Pública 36(4). https://doi.org/10.1590/0102-311×00054020

22. Rehman U, Shahnawaz MG, Khan NH, Kharshiing KD, Khursheed M, Gupta K Kashyap D, Uniyal R (2021) Depression, anxiety and stress among Indians in times of Covid-19 lockdown. Community Ment Health J 57(1):42-48. https:// doi.org/10.1007/s10597-020-00664-x

23. Shah SMA, Mohammad D, Qureshi MFH, Abbas MZ, Aleem S (2021) Prevalence, psychological responses and associated correlates of depression, anxiety and stress in a global population, during the coronavirus disease (COVID-19) pandemic. Community Ment Health J 57(1):101-110. https://doi. org/10.1007/s10597-020-00728-y

24. Ozamiz-Etxebarria N, Dosil-Santamaria M, Picaza-Gorrochategui M, IdoiagaMondragon N (2020) Stress, anxiety, and depression levels in the initial stage of the COVID-19 outbreak in a population sample in the northern Spain. Cad Saude Publica 36(4):e00054020. https://doi.org/10.1590/0102-311 X00054020

25. Cao W, Fang Z, Hou G, Han M, Xu X, Dong J, Zheng J (2020) The psychological impact of the COVID-19 epidemic on college students in China. Psychiatry Res 287:112934. https://doi.org/10.1016/j.psychres.2020.112934

26. Zhao H, He X, Fan G, Li L, Huang Q, Qiu Q, Kang Z, Du T, Han L, Ding L (2020) COVID-19 infection outbreak increases anxiety level of general public in China: involved mechanisms and influencing factors. J Affect Disord 276: 446-452. https://doi.org/10.1016/j.jad.2020.07.085

\section{Publisher's Note}

Springer Nature remains neutral with regard to jurisdictional claims in published maps and institutional affiliations.

\section{Submit your manuscript to a SpringerOpen ${ }^{\circ}$ journal and benefit from:}

- Convenient online submission

- Rigorous peer review

- Open access: articles freely available online

High visibility within the field

- Retaining the copyright to your article

Submit your next manuscript at $\boldsymbol{\nabla}$ springeropen.com 